\title{
WAR AND PEACE IN AFRICA: PHILOSOPHY, THEOLOGY AND THE POLITICS OF CONFRONTATION
}

\section{David W Lutz (ed.)}

California: Academica Press

2014, 284 pages

ISBN: 978-1-936320-09-7

The end of the Cold War did not result in the long awaited, lasting peace - it instead unleashed several old and new conflicts with many attempts at policing with economic, institutional, moral and legal means. The reality of current conflict hot spots in the world is stark: civil wars, wars against rebel groups and Islamists, popular uprisings, coups d'état and wars against narcotic groups. The subject of this book is very topical in current security studies on the African continent as it shies away from the contemporary model, instead focusing the attention on philosophy, theology and the politics of confrontation.

The authors contend that, although war is generally fought so that peace may be restored, in Africa, most wars are fought for other reasons, resulting in unjust wars becoming commonplace. While wars are generally studied from a jus ad bellum (decisions about going to war) and jus in bello (conduct in war) perspective, there also needs to be some dialogue on jus post bellum (restoration of peace after war). The book essentially attempts to deal with jus post bellum and the ethics of peace in Africa, trying to answer questions on the meaning of true peace and the possibility of having peace without justice, reconciliation and forgiveness.

The first essay, titled "Reflections on just war theory and pre-emptive war doctrine in an age of terrorism and violence", sets the scene for the remaining essays in that it deals with the changing nature of war - from those fought between sovereign states to defend territories, to liberation wars and, lastly, the war on terror (between sovereign states and groups not clearly organised and identified). The

Scientia Militaria, South African Journal of Military Studies, Vol 42, Nr 2, 2014, pp. 195-199. doi : $10.5787 / 42-2-1101$ essay accurately highlights the conditions necessary for just wars and then juxtaposes these onto (mainly the USA response to the 9/11 attacks) pre-emptive war doctrine, which the authors see as undermining the 
rules of war and the international systems of laws. According to the authors of this essay, these pre-emptive wars do not conform to just war theory, cannot have peace as an objective, expose the world to anarchy and require clear ethical standards. The essay is very applicable to the current situation in Africa in that any pre-emptive doctrine will seriously undermine any prospects of meaningful and lasting peace on the continent.

The next five essays narrow the focus to African examples by discussing insecurity in the Horn of Africa, non-violence in Kenya, the classification of wars in Africa, traditional means of reconciliation in Uganda, and an ethical approach to understanding the causes of war in the Great Lakes region. This section deals with the practicalities of philosophy, theology and the politics of confrontation.

In the Third World, there seems to be no dominant external security dilemma, and most countries are internally divided among contending forces. Contrary to the First World, leaders in Third World states adopt security management strategies which may seem brutal to outsiders. After going into extensive detail on the theory of national, regional and international security, the authors contextualise national security in the Horn of Africa by analysing the problems experienced. In this regard, security threats in the Horn of Africa are more internal than external, but these internal threats can manifest into external threats due to the porous borders of the area and the fact that most of the security issues transcend borders. Regional bodies, such as the Intergovernmental Authority on Development (IGAD), can play an important role in combating these threats.

The central theme in the essay on non-violence in Kenya is that peace does not equate to the absence of war. The essay highlights the vulnerability of the constitutional process when there is no equitable resource distribution, perceived justice or protection of minority rights. The adage by Donald Rumsveld that you do not know what you do not know clearly describes the situation in Kenya - until the people are informed as to what they are not getting, they will not know. The democratic process ensures that all are equal before the law and that all gain the same support/advantage from it. Highlighting of the levels of corruption, high salaries and preferential treatment for politicians by civil society and the media, strengthened the process to increase awareness. In Kenya, mass rallies, demonstrations, processions, strikes, sit-ins, vigils and prayers contributed to constitutional reform and a new constitution in 2010, but not after violence and deaths. Prolonged exploitation will in all cases lead to violent resistance.

The essay "War in theory and practice: The African experience" adopts a philosophical approach to the explanation of war and describes the nature of war and societies. War is studied in terms of its design and purpose and demarcated into cataclysmic (within the cosmic order), eschatological (globally orientated) and 
political (human ambit) schools. It is seen as man-made and within man's ability to control and eradicate. Africa is confronted by indigenous, religious, colonial and liberation wars which emanate from a greed for power and property - mostly wars over which the country has no control and for which the author provides many practical examples. The author of this essay contends that most wars in Africa are started and sustained as proxy wars by so-called Western backers that are hungry for power, profit and the spoils of war. While international laws and intervention can assist in containing and preventing wars, sustainable peace will only be achieved when we distinguish between justice and fairness, effective laws and lasting peace. There is a need for forgiveness and reconciliation in the world, and the author of this essay believes that this is only possible by the repentance of the greedy foreign sources of such wars, together with the development of the affected societies.

After discussing the political problems on the African continent as well as the major causes of conflict, the discussion on the Lord's Resistance Army (LRA) highlights the need for traditional means of conflict resolution. The essay highlights the roles of elders, clan leaders, families, traditional healers, friends and religious groups in this process. The author contends that, although the International Criminal Court may provide justice, it could also become a stumbling block to the peace process in the Ugandan region. The local population are calling for the application of a traditional Acholi justice system, called Mato Oput, which involves the community and promotes healing through a culture of non-violence, forgiveness, reconciliation and peace. In a way one could say that say that conflict resolution in Africa is not successful due to it not being based on African perspectives and values. This is different to the justice required in Western culture, which does not distinguish between moral and legal guilt.

The very narrow essay on scientific and technological progress for development with integrity attempts to alert the world to the dangers of unlimited progress in science and technology without any reference to ethics. It focuses on the negative effects of technological advances on humankind, such as global warming, radiation, ozone depletion and pollution. Scientific and technological advances also result in the proliferation of small arms, which contribute to conflict when available to rebel groups. The author contends that science and technology can be good but that it needs to be monitored for implementation. Science and technology could provide good solutions for prosperity and will influence society and the environment. The author generalises (p. 125) when he contends that global warming is responsible for the change in climate in the region. The author further harps on the negative effects of science and technology on conflict in the region missing the fact that there could also be other reasons for this conflict. 
The final section deals with the interrelationship between peace, justice and forgiveness and how these could lead to reconciliation.

Experiences of the Pökot community in Kenya highlight the fact that, in the African sense, there could be no peace without justice. The essay examines the African meaning of peace, theories of peace and the dimensions of reconciliation. Justice is seen as a necessary component in the realisation of true peace on the continent. The author describes three theories of peace: negative (might is right), idealistic (no disagreements) and comprehensive (the bigger picture). He argues that international institutions dealing with African issues should be African value-driven such as the Gacaca courts in Rwanda and the Truth and Reconciliation Commission in South Africa. Broken relationships with God, with self, with neighbours and with nature should be restored using the Pökot example of whole community involvement encompassing confession, well wishes or blessings and forgiveness. Justice will then be seen to be done.

The very philosophical essay on the mapping out of alternatives to war-led experiences declares that war in Africa is mostly associated with greed and that this greed together with corruption, political interference and leadership needs to be addressed. Africa is awash with consequences of conflict clearly illustrated by displacements in Uganda, Sudan and Zimbabwe. The essay emphasises the need for individuals such as Nelson Mandela, Betty Bigombe and Julius Nyerere, and for communities to be involved in the peace processes, which would lead to accountability, active political will, reflective thinking, capacity building, shared experiences and integrity. There is a need to build respect for human rights and to build a strong civil society. The author asserts that there could be no hope, innovation or future in a society that lacks peace at interpersonal, community and state levels.

Peace and justice are not mutually exclusive; they in fact complement each other. The essay on the relationship between peace and justice states that justice will result in mutual tolerance, mutual acceptance and mutual friendship, which will create a climate of peace which would, in turn, positively influence justice. Disregard for human dignity is seen as responsible for many transgressive acts against one another, and peace is thus not possible when dignity is ignored. Justice is regarded as an important element for all human beings and could be seen as the reason for the existence of civilisation as justice forms the foundation of all legal systems. Peace is a natural consequence of the conditions created by justice and could be seen as justice in action.

In the final essay on the gift of forgiveness, the author indicates that history is a fait accompli and irreversible and that all painful experiences are stored in human memory. Humans need redemption and need to forgive transgressors. 
Forgiveness is seen as a gift which is requested by the guilty and by definition not by the innocent, and has no exchange. Forgiveness can be difficult to understand, is always disproportional, and does not seek any other aim but reconciliation, although personal freedom, redemption and political or social healing could be positive spinoffs. Forgiveness is only targeted at the unforgiveable and leads to the admission that others are also good. Reactions to suffered evils are normally either intellectual silence or a desire for revenge - or one could opt for forgiveness. It is often difficult for survivors to forgive, and the face-to-face personal encounter implies often not forgiveness, but reconciliation. Nevertheless, forgiveness is considered essential in gaining closure, and so contributes to the conclusion of conflict.

This book discusses all of the above in detail and provides the reader with information not readily available in literature on wars in Africa and thus gives another perspective thereof. The fact that most of the authors are from Africa, that most of them had experienced wars first-hand and that most have played honourable roles in rebuilding communities affected by the ravages of conflict lends credibility to the book. On the negative side, the sequence of the chapters could have been explained in the introduction, as this could have assisted in guiding the reader through the very philosophical arguments in the book. Similarly, a closing chapter synthesising the main conclusions would have contributed to a sense of closure and would have assisted the reader in gaining a better understanding of these influences on conflicts and subsequent peace on the continent. Although not specifically stated, the authors, through the many examples, prove that true peace on the African continent will remain elusive without justice, reconciliation and forgiveness.

Mark Blaine, Faculty of Military Science, Stellenbosch University 